Annals of Warsaw University of Life Sciences - SGGW

Land Reclamation No 46 (1), 2014: 57-67

(Ann. Warsaw Univ. of Life Sci. - SGGW, Land Reclam. 46 (1), 2014)

\title{
Testing of reactive materials for phosphorus removal from water and wastewater - comparative study
}

\author{
AGNIESZKA KARCZMARCZYK, AGNIESZKA BUS \\ Department of Environmental Improvement, Warsaw University of Life Sciences - SGGW
}

\begin{abstract}
Testing of reactive materials for phosphorus removal from water and wastewater - comparative study. Excess of phosphorus in surface water is a global problem. Phosphorus found in rivers, streams, agricultural ditches and lakes comes from both point and diffuse sources. To keep water bodies in a good ecological status it is necessary to manage it a at local level. One of the possible solutions is to use reactive materials in wastewater treatment plants as well as in case of diffuse sources of pollution to implement it in water bodies transporting pollutants from small catchments. This paper presents results of research made over the period of 6 years (2008-2013) in the Department of Environmental Improvement and Water Center WULS-SGGW. Seventeen different materials available in Poland and in other parts of the world were tested as potential reactive materials for phosphorus. The most effective P-sorption reactive materials are: Polonite ${ }^{\mathbb{B}}$, shell sand, AAC, Pollytag and limestone with the apparent sorption capacities of: 94.32, 48.39, $43.17,28.95$, and $11.12 \mathrm{mg} / \mathrm{g}$ respectively.
\end{abstract}

Key words: phosphorus, reactive material, Langmuir isotherm, Freundlich isotherm

\section{INTRODUCTION}

The surplus of phosphorous $(\mathrm{P})$ in natural or artificial water bodies such as rivers, streams, drainage ditches, lakes, small agricultural pounds and reservoirs is considered as a major cause of water quality deterioration, increasing alga bloom and eutrophication process which make the water unable to future agriculture, economic or recreational use. The eutrophication process endanger not only lakes and water reservoirs but also slow-moving streams, estuaries and the Baltic Sea (Rönnberg and Bonsdorff 2004). Phosphorus in surface water originates from point sources, diffuse sources, atmospheric deposition and natural background sources (HELCOM 2006). However, the major sources of $\mathrm{P}$ in surface water are untreated or inadequately treated wastewaters, run off from agriculture areas, improper storage or inappropriate terms and doses of natural and mineral fertilizers. In case of diffuse P sources, which are directly connected with agriculture land use, the majority of $\mathrm{P}$ losses can be controlled by minimizing erosion and best management practices. However, all these actions are unable to significantly reduce dissolved P losses (Penn et al. 2011). The aim of Water Framework Directive is to achieved a good ecological status of surface water (e.g. rivers, lakes, transitional waters, and coastal waters) in the EU to the end of 2015 which is also connected with limiting $\mathrm{P}$ concentration in surface waters. Thus, it is important to implement an additional method for P reduction which can be based on implementation of reactive materials. 
Reactive materials are referred as adsorbents or sorbents and specially interact with targeted chemical species such as phosphate ions (Cucarella and Renman 2009). The P-sorption capacity of reactive materials is closely related to the content of $\mathrm{Ca}, \mathrm{Fe}$ and $\mathrm{Al}$ (Klimeski et al. 2012). Physical properties, such as hydraulic conductivity, porosity, grain size distribution, may also significantly influence P sorption (Johansson 2006).

Generally, P-sorption reactive materials may be divided into two groups, i.e. natural (e.g. apatite, bauxite, chalcedony, dolomite, gravel, granite, limestone, shell sand, shells, sands, serpentinite) and anthropogenic. Among the second group may be distinguished a man-made products (e.g. Filtra P, Filtralite P, LECA, LWA) invented especially to remove $P$ from water and wastewater, and industrial by-products (e.g. different kinds of ashes and slags, bricks) which are generated during a large variety of activities in society (Johansson 2006).

The first step to estimate P-sorption capacity of reactive material is to make laboratory experiments based on kinetic process. Thus, batch tests are often use method to estimate phosphorous-sorption capacity of reactive materials (Ádám et al. 2007a, Cucarella et al. 2007, Dunne et al. 2008, Hermann et al. 2012, Chmielewska et al. 2013). The most popular isotherms describe fitting experimental dates to empirical models that calculate sorption capacity are Langmuir and Freundlich (Vohla et al. 2011).
$P$ reactive materials may be used in constructed wetland system as an additional filter-step (Ádám et al. 2005, Shilton et al. 2006), in wastewater treatment (Ádám et al. 2007b), treatment agricultural wastewater run-off (Sibrell et al. 2009), P-removal structure to treat surface water runoff (Penn et al. 2012) and drainage outflow (Penn et al. 2007) and as a filling of biogeochemical barrier to protect surface water against nutrient flow (Kirkkala et al. 2012, Izydorczyk et al. 2013).

The aim of the paper is to assess and compare P-sorption capacity of different filtration materials to be used for removal phosphorus from water and wastewater.

\section{MATERIAL AND METHODS}

Seventeen different materials were tested in years 2008-2013 in the Laboratory of Ecotechnology in Department of Environmental Improvement and the Water Center WULS-SGGW (Fig. 1). Five of tested materials were of anthropogenic origin and twelve of natural. Anthropogenic materials were white brick $(90 \%$ of quartz sand, $7 \%$ of limestone, pressed with small amount of water in high temperature), red brick (clay heated in ca. $1,000^{\circ} \mathrm{C}$, main component is kaolinite $-\mathrm{Al}_{2} \mathrm{O}_{3} \cdot 2 \mathrm{SiO}_{2} \cdot \mathrm{H}_{2} \mathrm{O}$ ), autoclaved aerated concrete (AAC - lightweight construction material, mainly consists of tobermorite - $\left.\mathrm{Ca}_{5} \mathrm{Si}_{6} \mathrm{O}_{16}(\mathrm{OH})_{2} \cdot 4 \mathrm{H}_{2} \mathrm{O}\right)$, Pollytag (lightweight aggregate manufactured of fly ashes from thermal-electric power station) and LECA (light expanded clay aggregate consists of small, light- 
-weight, bloated particles of burnt clay). Tested materials of natural origin are: shells (external skeleton consists mainly of $\mathrm{CaCO}_{3}, \mathrm{Ca}_{5}\left[\mathrm{~F}\left(\mathrm{PO}_{4}, \mathrm{CO}_{3} \mathrm{OH}\right)_{3}\right]$, $\left.\mathrm{Ca}_{5}\left[\mathrm{OH}\left(\mathrm{PO}_{4}\right)_{3}\right]\right)$, shell sand (carbonatic material produced by shells, snails and coral alga), coral sand (also known as biogenic sand - sand of particles originating in tropical and sub-tropical marine environments from bioerosion of limestone skeletal material of marine organisms), black sand (found on beaches near a volcano, consists of tiny fragments of lava), and Philippine limestone (sedimentary rock, mostly contained of calcium carbonate). Those natural materials are available locally: shell has been brought from the Black Sea Side, Turkey; shell sand from the North Sea, Eggum, Norway; coral sand from Kadidiri, Gulf of Tomini, Indonesia; black sand from Parepare, Makassar Strait, Indonesia. Philippine limestone is commercially available in aquarium shops in Europe. The rest of natural materials are available globally. In the study were used: limestone (from coal mine in Bełchatów, consists mainly of calcium $(69 \%)$ in form of $\left.\mathrm{CaCO}_{3}\right)$, Polonite ${ }^{\circledR}$ (manufactured from the bedrock opoka, marine sediment belonging to a group of silica-calcite sediments found in deep strata in the eastern parts of Europe; in natural form it consists mainly of calcium carbonate $\left(\mathrm{CaCO}_{3}\right)$, which decomposes to calcium oxide $(\mathrm{CaO})$ while heated up to $900^{\circ} \mathrm{C}$ ), granite (consists mainly of quartz, mica, and feldspar; main element are silicon (Si) $18-34 \%$, al (Al) $4-8 \%$, and iron (Fe) $2-13 \%$ ), chalcedony (forms from watery silica gels at relatively low temperatures; can be found in weathering volcanic rocks and in sedimentary ones also) and serpentinite (metamorphic rock, consists predominantly of magnesium silicate and iron oxide minerals). Some of natural materials were also pretreated by heating in $900-1,000^{\circ} \mathrm{C}$ (shells, Philippine limestone and Polonite). Description of materials used in the study is presented in Table 1.

Varying concentrations of the artificial $\mathrm{P}$ solution prepared from $\mathrm{KH}_{2} \mathrm{PO}_{4}$ were used in the batch test for assessing Psorption capacity. The triplicate samples
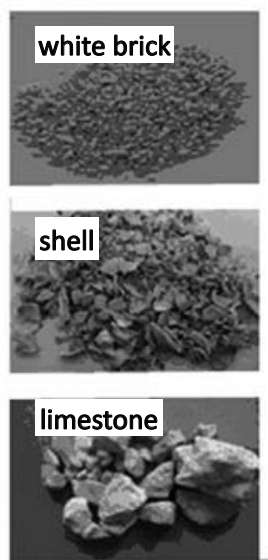
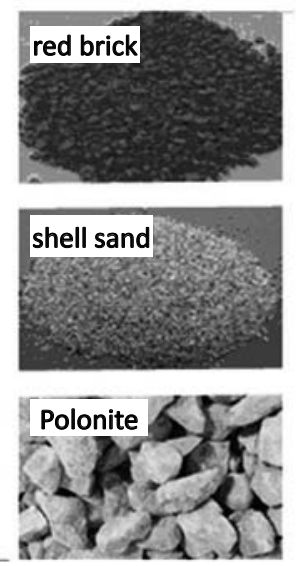
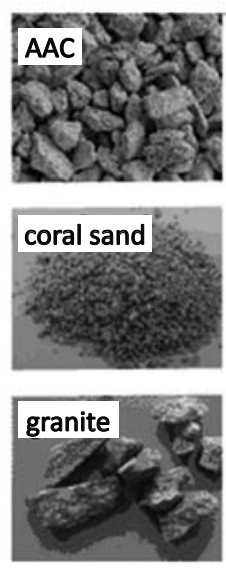
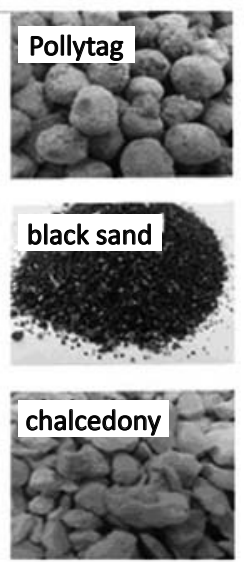
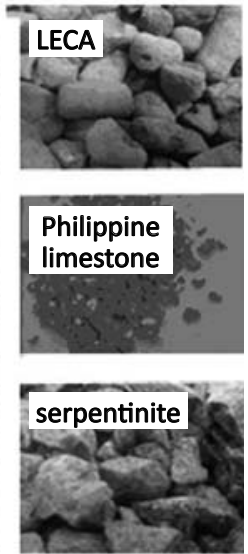

FIGURE 1. Filtration materials used for the sorption tests in the study 
TABLE 1. Materials used in the study with the focus on availability, pretreatment, grain size and performed sorption tests

\begin{tabular}{|l|c|c|c|c|}
\hline Material & Origin & Availability & Grain size & Isotherms \\
\hline White brick & anthropogenic & global & $2-5 \mathrm{~mm}$ & \\
\hline Red brick & anthropogenic & global & $2-5 \mathrm{~mm}$ & \\
\hline AAC & anthropogenic & global & $2-5 \mathrm{~mm}$ & $\sqrt{ }$ \\
\hline Pollytag & anthropogenic & global & $8-11 \mathrm{~mm}$ & $\sqrt{ }$ \\
\hline LECA & anthropogenic & global & $8-16 \mathrm{~mm}$ & \\
\hline Shells & natural & global & - & \\
\hline Shells heated & natural & global & - & \\
\hline Shell sand & natural & local & $1-5 \mathrm{~mm}$ & $\sqrt{ }$ \\
\hline Coral sand & natural & local & $0.5-2 \mathrm{~mm}$ & \\
\hline Black sand & natural & local & $0.25-1 \mathrm{~mm}$ & \\
\hline Philippine limestone & natural & local & $2-5 \mathrm{~mm}$ & \\
\hline Philippine limestone heated & natural & local & $2-5 \mathrm{~mm}$ & \\
\hline Limestone & natural & global & $2-4 \mathrm{~mm}$ & $\sqrt{ }$ \\
\hline Polonite & natural & local & $2-5 \mathrm{~mm}$ & $\sqrt{ }$ \\
\hline Granite & natural & global & $<1 \mathrm{~mm}$ & \\
\hline Chalcedony & natural & global & $1-9 \mathrm{~mm}$ & \\
\hline Serpentinite & natural & global & $6-17 \mathrm{~mm}$ & \\
\hline
\end{tabular}

- no date; $\sqrt{ }$ selected for Langmuir and Freundlich isotherms.

of material were mixed in Erlenmeyer glass flasks, each contained $1 \mathrm{~g}$ of reactive material $(5 \mathrm{~g}$ in case of LECA and serpentinite) and $100 \mathrm{~mL}$ of the various phosphorus solution added (from 1 to $1,200 \mathrm{mg} / \mathrm{L}$ ). Sorption tests were performed in short contact time of $15 \mathrm{~min}$ utes. P-sorption was calculated based on the difference of load of $\mathrm{P}$ added and obtained in a filtered sample.

Description of the sorption process between solid phase and solution was made based on mathematical equations given by Langmuir (McKay 1996):

$$
1 / q_{s}=1 / C_{s} \cdot 1 / K_{L}+a_{L} / K_{L}
$$

where:

$q_{s} \quad$ - sorption,

$C_{S}$ - solute concentration at equilibrium,
$K_{L}$ - constant parameter reflects the solute adsorptivity,

$a_{L}$ - constant parameter related to the energy of adsorption,

$K_{L} / a_{L}-$ ratio is defined as an adsorption capacity,

and Freundlich equation (McKay 1996):

$$
\log q_{s}=b_{F} \cdot \log C_{s}+\log a_{F}
$$

where:

$q_{s}$ - sorption,

$b_{F}$ - heterogeneity factor,

$C_{S}$ - solute concentration at equilibrium.

$a_{F}-$ constant which express the adsorbent capacity (the larger value, the higher the capacity).

The Langmuir isotherm describes adsorption on homogenous surfaces while 
Freundlich isotherm assumes surface which is heterogeneous.

\section{RESULTS AND DISCUSSION}

Sorption tests were performed for all tested materials to choose those potentially reactive for phosphorus. Initial $\mathrm{P}$ concentrations, $P$ reduction and obtained sorption are set in Table 2. Some of materials, e.g. white and red brick, LECA, shells, chalcedony, and serpentinite, were no active for phosphorus sorption. It can be surprising in case of LECA, which has been used for phosphorus sorption in different installations (Drizo et al. 1999, Jenssen and Krogstad 2003), however it is also commonly known, that LECA's properties depend on origin clay material, and they are different in different parts of the world. Based on the results (Table 2), five materials (limestone, shell sand, Polonite ${ }^{\circledR}, \mathrm{AAC}$, and Pollytag) have been selected for detailed sorption tests

TABLE 2. Initial $\mathrm{P}_{-} \mathrm{PO}_{4}$ concentrations $\left(C_{i n}\right), \mathrm{P}$ reduction and sorption obtained in batch tests of different materials

\begin{tabular}{|c|c|c|c|}
\hline Material & $C_{\text {in }}[\mathrm{mg} / \mathrm{L}]$ & P reduction [\%] & P sorption $[\mathrm{mg} / \mathrm{g}]$ \\
\hline White brick & 1.2 & 6.8 & 0.01 \\
\hline Red brick & 1.2 & - & - \\
\hline $\mathrm{AAC}$ & $\begin{array}{c}1.0 \\
2.0 \\
5.0 \\
10.0\end{array}$ & $\begin{array}{l}17.8 \\
16.1 \\
39.2 \\
50.5\end{array}$ & $\begin{array}{l}0.02 \\
0.03 \\
0.20 \\
0.50\end{array}$ \\
\hline Pollytag & $\begin{array}{c}1.0 \\
2.0 \\
10.0 \\
20.0 \\
50.0\end{array}$ & $\begin{array}{c}- \\
- \\
34.1 \\
45.9 \\
52.4\end{array}$ & $\begin{array}{c}- \\
- \\
0.34 \\
0.89 \\
2.67\end{array}$ \\
\hline LECA & $\begin{array}{c}1.0 \\
2.0 \\
5.0 \\
10.0 \\
20.0 \\
50.0\end{array}$ & $\begin{array}{l}- \\
- \\
- \\
- \\
- \\
-\end{array}$ & $\begin{array}{l}- \\
- \\
- \\
- \\
- \\
-\end{array}$ \\
\hline Shells & $\begin{array}{l}1.2 \\
5.2\end{array}$ & $\begin{array}{l}- \\
-\end{array}$ & $\begin{array}{l}- \\
-\end{array}$ \\
\hline Shells heated & $\begin{array}{l}1.2 \\
5.2\end{array}$ & $\begin{array}{l}1.1 \\
0.7\end{array}$ & $\begin{array}{l}0.00 \\
0.00\end{array}$ \\
\hline Shell sand & $\begin{array}{l}10.0 \\
20.0 \\
30.0 \\
50.0\end{array}$ & $\begin{array}{l}20.0 \\
31.0 \\
33.0 \\
18.0\end{array}$ & $\begin{array}{l}0.20 \\
0.62 \\
1.00 \\
0.70\end{array}$ \\
\hline Coral sand & $\begin{array}{c}1.0 \\
2.0 \\
5.0 \\
10.0\end{array}$ & $\begin{array}{l}23.0 \\
19.0 \\
10.1 \\
13.1\end{array}$ & $\begin{array}{l}0.02 \\
0.04 \\
0.05 \\
0.13\end{array}$ \\
\hline
\end{tabular}


Table 2 - cont.

\begin{tabular}{|c|c|c|c|}
\hline Material & $C_{\text {in }}[\mathrm{mg} / \mathrm{L}]$ & P reduction [\%] & P sorption $[\mathrm{mg} / \mathrm{g}]$ \\
\hline \multirow[t]{4}{*}{ Black sand } & 1.0 & - & - \\
\hline & 2.0 & - & - \\
\hline & 5.0 & 13.2 & 0.07 \\
\hline & 10.0 & 17.4 & 0.17 \\
\hline \multirow[t]{2}{*}{ Philippine limestone } & 1.4 & 14.6 & 0.02 \\
\hline & 5.6 & 7.6 & 0.04 \\
\hline \multirow[t]{2}{*}{ Philippine limestone heated } & 1.2 & 95.1 & 0.11 \\
\hline & 5.2 & 99.0 & 0.52 \\
\hline \multirow[t]{4}{*}{ Limestone } & 5.0 & 36.0 & 0.18 \\
\hline & 15.0 & 17.0 & 0.26 \\
\hline & 30.0 & 10.0 & 0.31 \\
\hline & 50.0 & 10.0 & 0.50 \\
\hline \multirow[t]{4}{*}{ Polonite $^{(R)}$} & 1.0 & 97.8 & 0.10 \\
\hline & 5.0 & 98.8 & 0.49 \\
\hline & 10.0 & 99.3 & 0.99 \\
\hline & 50.0 & 24.1 & 1.21 \\
\hline \multirow[t]{3}{*}{ Granite } & 10.0 & - & - \\
\hline & 20.0 & - & - \\
\hline & 30.0 & - & - \\
\hline \multirow[t]{6}{*}{ Chalcedony } & 1.0 & - & - \\
\hline & 2.0 & - & - \\
\hline & 5.0 & - & - \\
\hline & 10.0 & - & - \\
\hline & 20.0 & - & - \\
\hline & 50.0 & - & - \\
\hline \multirow[t]{6}{*}{ Serpentinite } & 1.0 & - & - \\
\hline & 2.0 & - & - \\
\hline & 5.0 & - & - \\
\hline & 10.0 & - & - \\
\hline & 20.0 & - & - \\
\hline & 50.0 & - & - \\
\hline
\end{tabular}

- no P reduction/no P sorption observed.

(Tables 3 and 4). Those materials are: limestone, shell sand, Polonite ${ }^{\circledR}, \mathrm{AAC}$, and Pollytag.

The lowest sorption of phosphorus was observed for natural limestone, which was obtained from Bełchatów. However, its P-sorption capacity was quite high (Table 4), comparing natural limestones described by other researchers (Drizo et al. 1999, Johansson 1999, Zhou and Li 2001). The most reactive for phosphorus were Polonite and AAC (Fig. 2).
The highest P-sorption capacity $(94.32 \mathrm{mg} / \mathrm{g})$ was obtained for Polonite ${ }^{\mathbb{B}}$. This result is comparable with the data given by Brogowski and Renman (2004) or Cucarella et al. (2007). The highest value of Freundlich constant $a_{F}$ also proved that. Based on the phosphorus-sorption capacity, tested reactive materials can be put in range as follows: Polonite $^{\circledR}>$ shell sand $>$ AAC $>$ Pollytag $>$ $>$ limestone (Table 4). 
TABLE 3. Values of Langmuir and Freundlich isotherms approximation constants calculated for the reactive materials used in the study

\begin{tabular}{|l|c|c|c|c|c|c|c|c|}
\hline \multirow{2}{*}{ Material } & \multirow{2}{*}{$\begin{array}{c}\text { Grain size } \\
{[\mathrm{mm}]}\end{array}$} & \multirow{2}{*}{$C_{i n}[\mathrm{mg} / \mathrm{L}]$} & \multicolumn{3}{|c|}{ Langmuir isotherm } & \multicolumn{3}{|c|}{ Freundlich isotherm } \\
\cline { 4 - 9 } & & & $K_{L}$ & $a_{L}$ & $\mathrm{R}^{2}$ & $a_{F}$ & $b_{F}$ & $\mathrm{R}^{2}$ \\
\hline Limestone & $2.00-4.00$ & $5-1,200$ & 42.684 & 0.9100 & 81 & 0.4366 & 2.5029 & 86 \\
\hline Shell sand & $1.00-5.00$ & $10-1,000$ & 19.200 & 0.3968 & 67 & 0.5689 & 2.1087 & 84 \\
\hline Polonite & $2.00-5.00$ & $1-1,000$ & 10.469 & 0.1110 & 93 & 0.6551 & 2.2662 & 94 \\
\hline AAC & $2.00-5.00$ & $1-1,000$ & 27.010 & 0.6258 & 98 & 0.8779 & 3.323 & 99 \\
\hline Pollytag & $8.00-11.00$ & $1-1,000$ & 13.411 & 0.4632 & 63 & 0.4333 & 1.5052 & 56 \\
\hline
\end{tabular}

$C_{\text {in }}$ - initial concentration, $K_{L}$ - constant parameter reflects the solute adsorptivity, $a_{L}-$ constant parameter related to the energy of adsorption, $a_{F}$ - constant expressing the adsorbent capacity, $b_{F}$ - heterogeneity factor.

TABLE 4. Values of apparent P-sorption capacity obtained from the Langmuir isotherm

\begin{tabular}{|lccccc|}
\hline Reactive material & Limestone & Shell sand & Polonite & AAC & Pollytag \\
\hline $\mathrm{S}_{\max }[\mathrm{mg} / \mathrm{g}]$ & 11.12 & 48.39 & 94.32 & 43.17 & 28.95 \\
\hline
\end{tabular}

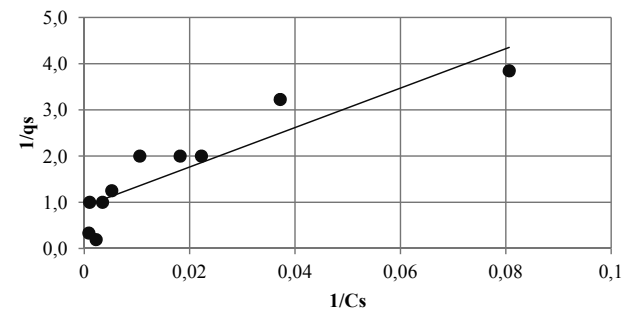

- limestone 2-4 mm

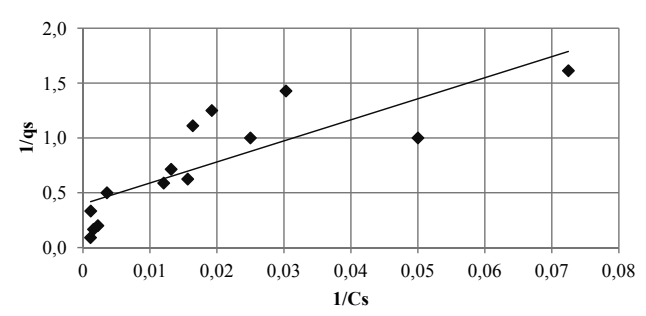

• shell sand 1-5 mm

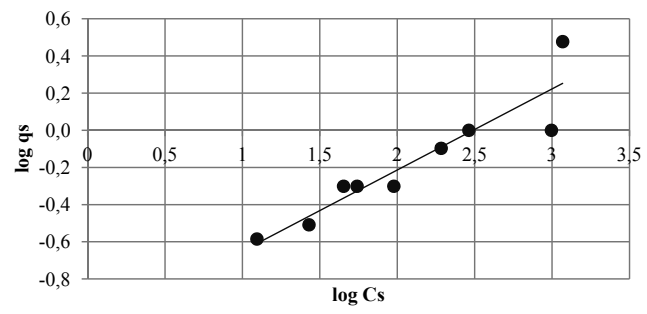

- limestone 2-4 mm

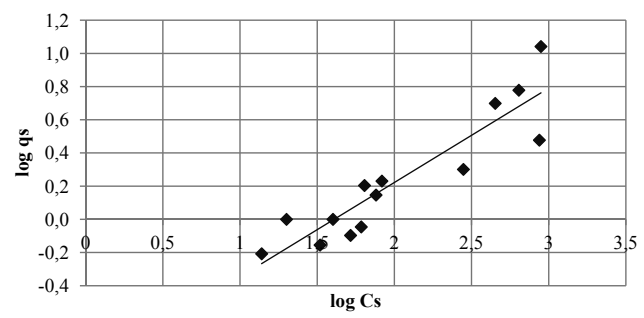

४ shell sand 1-5 mm

FIGURE 2. Langmuir (left) and Freundlich (right) isotherm constants approximation for limestone, shell sand, Polonite ${ }^{\circledR}, \mathrm{AAC}$ and Pollytag 


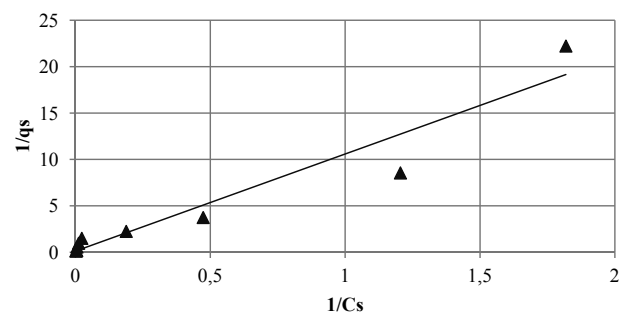

$\Delta$ Polonite 2-5 mm

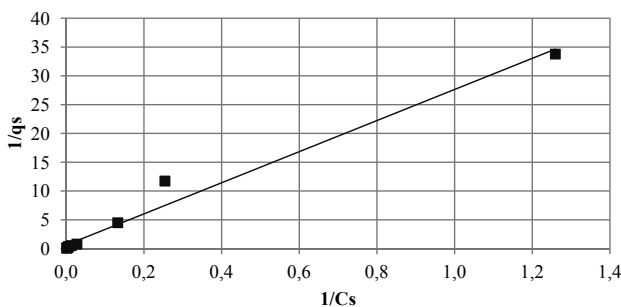

- AAC 2-5 mm

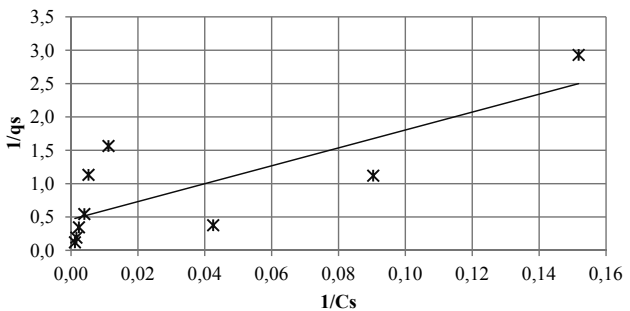

*Pollytag 8-11 mm

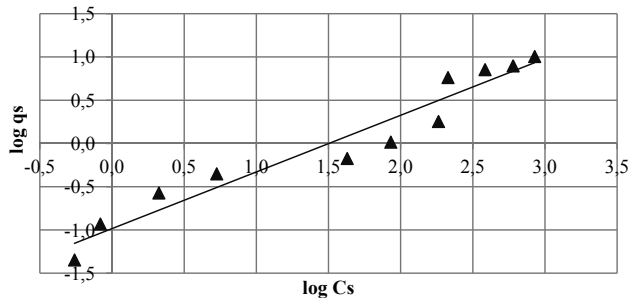

$\Delta$ Polonite $2-5 \mathrm{~mm}$

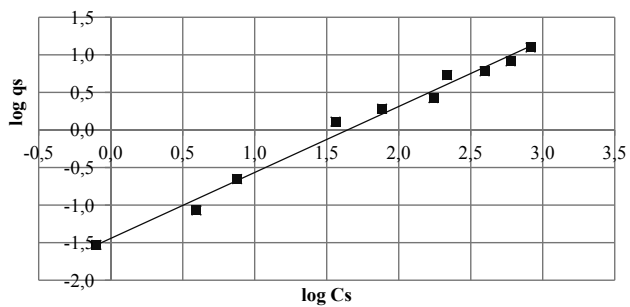

- AAC 2-5 mm

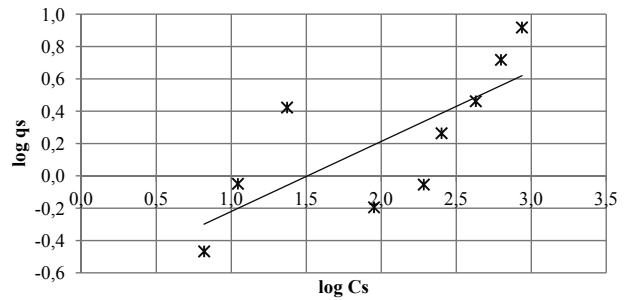

*Pollytag 8-11 mm

FIGURE 2 (continued). Langmuir (left) and Freundlich (right) isotherm constants approximation for limestone, shell sand, Polonite ${ }^{\circledR}$, AAC and Pollytag

To be used as a reactive material for $P$ removal from water or wastewater reactive materials should be (1) effective, (2) available and (3) not expensive.

Polonite is a commercial product from opoka, activated for P sorption by thermal treatment. The efficiency of the material is very high, however mining and heating is energy-consuming process. The chemical composition of Polonite can vary due to quality of origin material (Bus and Karczmarczyk 2014), thus why sorption capacity should be tested for each lot. AAC is commonly use artificial construction material, so it is homogenous. Special interest should be put into using AAC from demolition process, which will make reactive material more sustainable. Both Polonite and AAC are available in Europe and can be trade to other countries.

Pollytag, which is also effective for $\mathrm{P}$ removal, is a commercial product made from fly ashes from thermal-electric 
power station, and can be traded worldwide if necessary. The price of the $1 \mathrm{Mg}$ of Pollytag amounts about 50 euro. It is three times less effective than Polonite, however it should be noted, that the fraction of tested Pollytag was the biggest.

Shell sand is natural carbonate material, which is available only in local scale. It was tested before by Roseth (2000), S $\varnothing$ vik and Kløve (2005) and Adam et al. (2007a). The highest sorption obtained in cited research was as high as $17 \mathrm{mg} / \mathrm{g}$ (Roseth 2000), which is much less than in presented study. However, the conditions of experiments e.g. initial $\mathrm{P}$ concentration and contact time were also different. Concerning the availability, shell sand can be used as effective $\mathrm{P}$ sorbent where it is available.

\section{CONCLUSIONS}

High P-sorption capacity of selected reactive materials gives the potential of their applications in wastewater streams and small water bodies. They can be implement as a separate filters in onsite wastewater treatment plants or as a supporting layer in constructed wetlands, sand filters and infiltration systems. Reactive materials can be also use to mitigate phosphorus pollution from non-point sources in form of reactive barriers, box filters or suspended filters (patent application p.403571) located in small streams, ditches or small agricultural ponds.

Among the studied reactive materials Polonite is characterized by the highest sorption capacity $(94.32 \mathrm{mg} / \mathrm{g})$. Almost two times lower sorption capacity than Polonite have shell sand $(48.39 \mathrm{mg} / \mathrm{g})$ and AAC $(43.17 \mathrm{mg} / \mathrm{g})$, three times lower sorption capacity is characterized by Pollytag $(28.95 \mathrm{mg} / \mathrm{g})$ and almost eight times lower sorption capacity for limestone $(11.12 \mathrm{mg} / \mathrm{g})$. Some of potential P-sorption materials such as white and red brick, LECA, shells, chalcedony and serpentinite have been non-reactive with phosphorous.

Most of tested materials are available globally, some of them only in local scale. From that group shell sand is promising medium to be used e.g. in Norway; coral sand, black volcanic sand, and Philippine limestone (heated) can be used in East Asia.

\section{Acknowledgments}

Authors would like to thank Bioptech

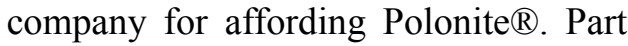
of the research was made in the Laboratory of Ecotechnology Water Center SGGW.

\section{REFERENCES}

ÁDÁM K., KROGSTAD T., SULIMAN E.R.D., JENSSEN P.D. 2005: Phosphorus sorption by Filtralite $\mathrm{P}$ - small scale box experiments. J. Environ. Sci. Health. 40: 1239-1250.

ÁDÁM K., SøVIK A.K., KROGSTAD T., HEISTAD A. 2007a: Phosphorus Removal by the Filter Materials Light-Weight Aggregates and Shell Sand - A Review of Processes and Experimental Set-ups for Improved Design of Filter Systems for Wastewater Treatment. Vatten. 63: 245-257.

ÁDÁM K., KROGSTAD T., VRĹLE L., S $\varnothing$ VIK A.K., JENSSEN P.D. 2007b: Phosphorus retention in the filter materials shellsand and Filtralite $\mathrm{P}^{\circledR}$-Batch and column experiment with synthetic $\mathrm{P}$ 
solution and secondary wastewater. Ecol. Eng. 29: 200-208.

BROGOWSKI Z., RENMAN G. 2004: Characterisation of opoka as a basis for its use in wastewater treatment. Pol. J. Environ. Stud. 13 (1): 15-20.

BUS A., KARCZMARCZYK A., 2014: Properties of lime-siliceous rock opoka as a reactive material to remove phosphorous from surface water and sewage. Infrastructure and Ecology of Rural Area (in press).

CHMIELEWSKA E., HODOSSYOVÁ R., BUJDOŠ M. 2013: Kinetic and termodynamic studies for phosphorous removal using natural adsorption materials. Pol. J. Environ. Stud. 22(5): 1307-1316.

CUCARELLA V., ZALEWSKI T., MAZUREK R., 2007: Phosphorous sorption capacity of different types of opoka. Ann. Warsaw Agricult. Univ. - SGGW, Land Reclam. 38: 11-18.

CUCARELLA V., RENMAN G. 2009: Phosphorus Sorption Capacity of Filter Materials Used for On-Site Wastewater Treatment Determined in Batch Experiments - A Comparative Study. J. Environ. Qual. 38: 381-392.

DRIZO A., FROST C.A., GRACE J., SMITH K.A. 1999: Phisico-chemical screening of phosphate-removing substrates for use in constructed wetland systems. Wat. Res. 33 (17): 3595-3602.

DUNNE E.J., REDDY K.R., LEADER J.W. 2008: Phosphorous sorbing materials: Sorption dynamics and physicochemical characteristics. J. Environ. Qual. 37: 174-181

HELCOM Thematic Assessment in 2006 Eutrophication in the Baltic Sea, HELCOM Stakeholder Conference on the Baltic Sea Action Plan Helsinki, Finland, 7 March 2006, www.helcom.com.

HERMANN I., JOURAKA., LUNDSTRÖM T.S., HEDSTRÖM A., VIKLANDER M. 2012: Phosphprous binding to Filtra $\mathrm{P}$ in batch tests. Environ. Tech. 33 (9), 1013-1019.
IZYDORCZYK K., FRĄTCZAK W., DROBNIEWSKA A., CICHOWICZ E., MICHALSKA-HEJDUK D., GROSS R., ZALEWSKI M. 2013: A biogeochemical barrier to enhance a buffer zone for reducing diffuse phosphorus pollution - preliminary results, Ecohydrol. Hydrobiol. 13, 104-112.

JENSSEN P.D., KROGSTAD T. 2003: Design of constructed wetlands Rusing phosphorus sorbing lightwaight aggregate (LWA). In: Ü. Mander, P.D. Janssen (Eds) Contructed Wetlands for Wastewater Treatment in Cold Climates, Advances in Ecological Sciences 11. WIT PRESS, Southamption, Boston: 259-272.

JOHANSSON L. 1999: Industrial by-products and natural substrata as phosphorus sorbents. Environ. Technol. 20: 309-316.

JOHANSSON WESTHOLM L. 2006: Substrates for phosphorus removal - Potential benefits for on-site wastewater treatment? Water Res. 40: 23-36.

KIRKKALA T., VENTELÄ A.-M., TARVAINEN M. 2012: Long-Term Field-Scale Experiment on Using Lime Filters in an Agricultural Catchment. J. Environ. Qual. 41: 410-419.

KLIMESKI A., CHARDON W.J., TURTOLA E., UUSITALO R. 2012: Potential and limitations of phosphate retention media on water protection: A process-based review of laboratory and field-scale tests. Agric. Food Sci. 21: 206-223.

McKAY G. (Ed.) 1996: Use of Adsorbents for the Removal of Pollutants from wastewater. CRC Press, Boca Raton: 179.

Patent application p.403571 from 14.04.2013: Suspended filters for pollutants removal from surface water streams and lakes. A. Karczmarczyk, A. Bus. Warsaw University of Life Sciences - SGGW.

PENN C.J., BRYANT R.B., KLEINMAN P.J.A., ALLEN A.L. 2007: Removing Dissolved Phosphorus from Drainage Ditch Water with Phosphorus Sorbing Materials. J. Soil Water Conserv. 62 (4): 269-276. 
PENN C.J., BRYANT R.B., CALLAHAN M.P., MCGRATH J.M. 2011: Use of industrial by-product to sorb and retain phosphorous. Commun. Soil Sci. Plant Anal. 42: 633-644.

PENN C.J., MCGRATH J.M., ROUNDS E., FOX G., HEEREN D., 2012: Trapping Phosphorus in Runoff with a Phosphorus Removal Structure. J. Environ. Qual. 41: 672-679.

ROSETH R. 2000: Shellsand: a new filter medium for constructed wetlands and wastewater treatment. J. Environ. Sci. Health 35 (8): 1335-1355.

RÖNNBERG C., BONSDORFF E. 2004: Baltic Sea eutrophication: area-specific ecological consequences. Hydrobiologia 514: 227-241.

SHILTON N., ELMETRI I., DRIZO A., PRATT S., HAVERKAMP R. G., BILBY S.C. 2006: Phosphorus Removal by an 'Active' Slag Filter-a Decade of Full Scale Experience. Water Res. 40 (1): 113-118.

SIBRELL P.L., MONTGOMERY G.A., RITENOUR K.L., TUCKER T.W. 2009: Removal of Phosphorous from Agricultural Wastewaters Using Adsorption Media Prepared from Acid Mine Drainage Sludge. Water Res. 43: 2240-2250.

S $\varnothing$ VIK A., KL $\varnothing$ VE B. 2005: Phosphorus retention processes in shell sand filter systems treating municipal wastewater. Ecol. Eng. 25: 168-182.

VOHLA C., KÖIV M., BAVOR H.J., CHAZARENC F., MANDER Ü. 2011: Filter Materials for Phosphorus Removal from Wastewater in Treatment Wetlands -A Review. Eco. Eng. 37(1): 70-89.

ZHOU M., LI Y. 2001: Phosphorus-sorption characteristics of calcareous soils and limestone from the southern Everglades and adjacent farmlands. Soil Sci. Soc. Am. J. 65: 1404-1412.

Streszczenie: Badanie materiatów reaktywnych do usuwania fosforu $z$ wód i ścieków - studium porównawcze. Obecność nadmiernych stężeń fosforu w wodach powierzchniowych jest problemem globalnym. Fosfor występujący w rzekach, strumieniach, rowach i jeziorach pochodzi zarówno ze źródeł punktowych, jak i obszarowych. Aby utrzymać wody w dobrym stanie ekologicznym, należy podejmować działania na poziomie lokalnym. Jednym z możliwych rozwiązań jest zastosowanie materiałów reaktywnych w oczyszczalniach ścieków, jak również w przypadku obszarowych źródeł zanieczyszczeń w małych ciekach wodnych. W artykule przedstawiono wyniki badań prowadzonych w ciagu ostatnich 6 lat w Katedrze Kształtowania Środowiska i Centrum Wodnym SGGW. Siedemnaście różnych materiałów dostępnych zarówno w Polsce, jak i w innych częściach świata testowano jako potencjalne materiały reaktywne do usuwania fosforu. Najbardziej efektywnymi materiałami są: Polonite ${ }^{\circledR}$, shell sand, AAC, Pollytag oraz wapień, dla których maksymalną zdolność sorpcyjną dla fosforu określono na poziomie odpowiednio: 94,$32 ; 48,39 ; 43,17 ; 28,95$ i $11,12 \mathrm{mg} / \mathrm{g}$.

Stowa kluczowe: fosfor, materiał reaktywny, izoterma Freundlicha, izoterma Langmuira

\section{MS. received in February 2014}

\section{Authors' address:}

Agnieszka Karczmarczyk, Agnieszka Bus

Katedra Kształtowania Srodowiska

Wydział Budownictwa i Inżynierii Środowiska

SGGW

ul. Nowoursynowska 159

02-776 Warszawa, Poland

e-mail: agnieszka_karczmarczyk@sggw.pl agnieszka_bus@sggw.pl 